\title{
GAMBARAN FAKTOR RISIKO PADA PEGAWAI OPERATOR KOMPUTER YANG MEMILIKI GEJALA CARPAL TUNNEL SYNDROME DI RSUD ABDUL MANAP TAHUN 2020
}

\author{
Winiesti Melani Putri, Mirna Marhami Iskandar, Citra Maharani \\ Fakultas Kedokteran dan Ilmu kesehatan Universitas Jambi \\ Corresponding author email: winiesti@gmail.com
}

\begin{abstract}
Carpal Tunnel Syndrome (CTS) is a work-related disease that involves the upper extremities, espsecially the wrists. The prevalence of CTS according to NIOSH (The national Institute for Occupational Safety and Healthy) is $15-20 \%$, while in Indonesia was undiscovered. This research is describing the risk factors for Carpal Tunnel Syndrome in computer operators who have CTS symptoms consist of individual risk that is age, gender, BMI, and Diabetes melitus, and risk factors as a computer operator that is awkward posture, repetitive movements, and duration of work. This research is a qualitative descriptive study that involving 13 respondents using purposive sampling technique. This study uses research data obtained by structured interviews, BMI measurement, blood sugar level measurement, phalen test, tinnel tes, and direct observation with tape recording while operators typing. The results in this research of the 13 respondents, was found that the risk factors for CTS in computer operators who had CTS symptoms were most on 31 60 years old (69,2\%), female (69,2\%), Normal BMI (53,,8\%) negative DM (92,3\%), awkward posture $\geq 30$ times perminute (100\%), repetitive movements $>30$ times perminute (100\%) and work period as a computer operator $\geq 4$ years (86,6\%). Based on individual risk factors respondents who had CTS symptoms were mostly found in aged 31-60 years old, female, normal BMI, negative DM, while based on occupational risk factors were mostly found in respondents with work period $\geq 4$ years, repetitive movements and awkward postures $>30$ time perminute.
\end{abstract}

Keywords: Carpal tunnel Syndrome, Risk Factors for CTS.

\section{ABSTRAK}

Carpal Tunnel Syndrome (CTS) merupakan salah satu penyakit akibat kerja yang melibatkan ekstremitas atas khususnya pada pergelangan tangan. Prevalensi CTS menurut NIOSH ( The National Institute for Occupational Safety and Healthy) adalah sebesar 15-20\%, sedangkan di Indonesia sendiri belum diketahui. Penelitian ini untuk mendeskripsikan faktor risiko Carpal Tunnel Syndrome pada operator komputer yang memiliki gejala CTS berupa faktor risiko individu yaitu, Usia, Jenis Kelamin, IMT, dan Diabetes Melitus serta faktor risiko pekerjaan sebagai operator komputer yaitu, postur janggal, gerakan repetitive, durasi kerja. Penelitian ini merupakan penelitian deskriptif kualitatif. Sampel pada penelitian ini berjumlah 13 orang dengan menggunakan teknik purposive sampling. Penelitian ini menggunakan data penelitian yang diperoleh melalui wawancara terstruktur, pengukuran IMT, pengukuran kadar gula darah, melakukan uji phalen test dan tinel test serta observasi langsung dan merekam operator komputer saat mengetik. Hasil penelitian terhadap ke-13 responden, didapatkan bahwa faktor risiko CTS pada operator komputer yang memiliki gejala CTS paling banyak berusia 31-60 tahun (69,2\%), jenis kelamin perempuan $(69,2 \%)$, IMT normal $(53,8 \%)$, DM negatif $(92,3 \%)$, postur janggal $\geq 30$ kali permenit (100\%), gerakan repetitif $>30$ kali permenit (100\%), masa kerja sebagai operator komputer $\geq 4$ tahun $(86,6 \%)$. Berdasarkan 
faktor risiko individu, responden yang memiliki gejala CTS paling banyak ditemukan pada responden usia 31-60 tahun, berjenis kelamin perempuan, IMT normal dan Kriteria DM negatif, sedangkan berdasarkan faktor risiko pekerjaan paling banyak ditemukan pada responden dengan masa kerja $\geq 4$ tahun, dengan gerakan repetitif dan postur janggal $>30$ kali permenit.

Kata Kunci: Carpal Tunnel Syndrome, Faktor Risiko CTS

\section{PENDAHULUAN}

Tangan merupakan salah satu anggota gerak tubuh yang paling sering digunakan dalam berbagai aktivitas seharihari. Aktivitas tangan dan pergelangan tangan yang berlebihan jika berlangsung lama dapat menimbulkan suatu masalah. Masalah yang ditimbulkan akibat aktivitas yang berlebihan pada tangan akan mempengaruhi risiko penyakit akibat kerja. Penyakit akibat kerja adalah gangguan kesehatan baik jasmani maupun rohani yang ditimbulkan atau diperparah karena aktivitas kerja atau kondisi yang berhubungan dengan pekerjaan dan jika hal ini terjadi pada pergelangan tangan akan menimbulkan penyakit akibat kerja salah satunya adalah Carpal Tunnel Syndrome. ${ }^{1}$

\section{Carpal Tunnel Syndrome (CTS)} merupakan salah satu penyakit akibat kerja. ${ }^{1}$ Laporan International Labour Organization (ILO) menunjukkan bahwa CTS hampir selalu ditemukan dalam setiap kasus penyakit akibat kerja di beberapa negara. Bahkan di negara Cina pada tahun 2010 terjadi peningkatan jumlah kasus CTS akibat kerja sebesar kurang lebih 30\% dibandingkan tahun 2001. Tingginya angka prevalensi yang diikuti dengan tingginya biaya yang harus dikeluarkan (pengobatan medis, rehabilitasi, kompensasi hilangnya jam kerja, biaya pensiun awal, juga pelatihan pekerja baru, dan lain-lain) membuat permasalahan ini menjadi masalah besar dalam dunia okupasi. ${ }^{2}$

Prevalensi CTS sebagai penyakit akibat kerja di Indonesia belum diketahui karena masih sangat sedikit diagnosis penyakit akibat kerja yang dilaporkan. Hasil penelitian Lazurdi (2015), tentang gejala CTS pada pekerja pemecah batu di Kabupaten Jember, menujukkan bahwa prevalensi CTS pada pekerja dengan risiko tinggi pada pergelangan tangan dan tangan mencapai 5,6\% sampai dengan $15 \% .{ }^{3}$ Hasil penelitian lain tentang CTS pada pekerja garmen di Jakarta, menunjukkan bahwa prevalensi CTS karena faktor risiko pekerjaan mencapai $20,3 \%{ }^{4}$

Faktor risiko kejadian CTS dikelompokkan menjadi 2 kelompok, yakni faktor risiko terkait individu dan faktor risiko terkait pekerjaan. ${ }^{5}$ Faktor- faktor yang terkait dengan individu diantaranya usia. Pertambahan usia dapat memperbesar risiko terjadinya CTS, biasanya terjadi pada usia $30-60$ tahun. $^{6}$ Jenis kelamin juga berperan sebagai faktor risiko CTS. Perempuan berisiko 3 kali lipat lebih banyak dibandingkan dengan laki-laki. ${ }^{7}$ Selain itu, CTS juga dapat terjadi karena kompresi saraf di bawah ligamentum karpal transversal berhubungan dengan naiknya berat badan dan Indeks Massa Tubuh (IMT). ${ }^{3} \quad$ Hasil studi di Taiwan (2015) 
menyatakan bahwa pasien dengan diabetes melitus memiliki resiko lebih tinggi untuk terkena DHS (Diabetic Hand Syndrome), salah satunya adalah CTS. ${ }^{8}$

Penelitian Roquelaure dkk (2008) menunjukkan bahwa tingkat kejadian CTS lebih tinggi pada individu yang bekerja dibanding dengan individu tidak bekerja. ${ }^{9}$ Faktor risiko yang terkait dengan pekerjaan diantaranya gerakan yang berulang (gerakan repetitive), durasi kerja yang lama, dan posisi tangan yang salah. ${ }^{10}$ South Texas Veterans Health Care System (2006) di San Antonio, Texas, Amerika Serikat mengemukakan bahwa CTS itu merupakan penyakit yang berhubungan dengan komputer pada sebagian besar populasi di Amerika. Contohnya pada pekerja kantor yang memerlukan fleksi atau ekstensi jari berulang dalam waktu yang lama, terutama juru ketik dan petugas pemasukan data. Penggunaan perangkat elektronik secara statis dalam waktu yang lama terutama komputer dapat memengaruhi muskuloskeletal pekerja kantor. Hal ini disebabkan oleh posisi tangan yang salah (postur janggal) pada saat menggunakan mouse atau keyboard dan pekerjaan yang berulang (repetitive work). Penggunaan keyboard lebih dari empat jam per hari merupakan faktor risiko keluhan nyeri pada tangan. ${ }^{9}$

The National Institute for Occupational Safety and Healthy (NIOSH) tahun 2007 menyebutkan bahwa orang Amerika mempunyai risiko CTS sebesar 15-20\%. ${ }^{11}$ Carpal tunnel syndrome didefinisikan sebagai kompresi nervus medianus pada pergelangan tangan dan termasuk sindrom kompresif yang paling sering terjadi. Insidensi cukup tinggi yaitu $3,8 \%$ populasi dunia. Pada tahun 2001, CTS menempati posisi keenam dari semua penyakit akibat kerja di Uni Eropa dan sejak tahun 2003 CTS termasuk ke dalam daftar penyakit akibat kerja di Uni Eropa. ${ }^{9}$

Berdasarkan latar belakang tersebut yang menunjukkan bahwa operator komputer merupakan jenis pekerjaan yang sangat beresiko terkena penyakit CTS karena operator komputer sering melakukan gerakan yang berulang dan memposisikan tangannya pada postur yang salah ketika mengetik, termasuk pegawai operator komputer di Rumah Sakit. Gejala CTS yang muncul diawal pada umumnya akan diabaikan dan dianggap suatu hal yang kecil, sehingga orang-orang umumnya tidak langsung memeriksakannya ke fasilitas pelayanan kesehatan bahkan bagi mereka yang bekerja langsung di fasilitas pelayanan kesehatan tersebut, serta terbatasnya penelitian mengenai faktor risiko CTS pada pekerja operator komputer di Indonesia, maka peneliti tertarik untuk meneliti gambaran faktor risiko pada pegawai operator komputer yang memiliki gejala CTS di RSUD Abdul Manap tahun 2020.

\section{METODE}

Penelitian ini dilakukan dengan metode deskriptif kualitatif agar diketahui secara jelas dan lebih mendalam tentang gambaran faktor risiko pada pegawai operator komputer yang memiliki gejala CTS di RSUD Abdul Manap Tahun 2020. Penelitian ini dilakukan di RSUD Abdul 
Manap Kota Jambi dari bulan Juli hingga November 2020.

Responden dalam penelitian ini
dipilih berdasarkan dengan asas
kesesuaian (appropriateness) dan asas
kecukupan (adequacy).
pengetahuan yang berkaitan dengan topik penelitian. Pemilihan responden berdasarkan asas kecukupan adalah responden yang dapat menggambarkan seluruh fenomena yang berkaitan dengan topik penelitian. Teknik sampling yang digunakan dalam penelitian ini menggunakan teknik purposive sampling. Berdasarkan asas pemilihan responden dan teknik pengambilan sampel penelitian maka responden dalam penelitian ini dengan rincian sebagai berikut:

1. Pegawai operator komputer di ruang kepegawaian RSUD Abdul Manap yang memiliki gejala CTS

2. Pegawai operator komputer di ruang keuangan RSUD Abdul Manap yang memiliki gejala CTS

3. Pegawai operator komputer diruang medical record RSUD Abdul Manap yang memiliki gejala CTS

4. Pegawai operator komputer di ruang front office RSUD Abdul Manap yang memiliki gejala CTS

5. Pegawai operator komputer di ruang verifikator BPJS RSUD Abdul Manap yang memiliki gejala CTS

Penelitian ini menggunakan instrumen berupa peneliti sendiri dan beberapa instrument bantuan yaitu sebagai berikut:
Penelitian ini menggunakan instrumen berupa peneliti sendiri dan beberapa instrument bantuan yaitu sebagai berikut:

1) pedoman wawancara terstruktur. Ini adalah suatu tulisan singkat yang berisikan daftar informasi yang perlu dikumpulkan. Pertanyaan-pertanyaan lazimnya bersifat telah dibuat dan disusun sebelumnya.

2) Alat perekam.

Peneliti dapat menggunakan alat perekam seperti, tape recorder, kamera foto, dan kamera video. Alat perekam dapat dipergunakan apabila peneliti mengalami kesulitan untuk mencatat hasil wawancara.

3) Alat ukur berat badan dan alat ukur tinggi badan (mikrotois)

Untuk mengukur berat badan dan tinggi badan responden agar dapat mengukur IMT dari responden.

4) Blood glucose meter (alat ukur gula darah)

Peneliti menggunakan alat ukur gula darah untuk mengukur gula darah sewaktu dari responden agar dapat mengetahui kadar gula darah sewaktu apakah normal atau tidak, sehingga dapat menjadi sumber data penguat setelah hasil wawancara apakah responden menderita diabetes melitus atau tidak.

5) Stopwatch

Alat ini digunakan untuk melihat adakah gerakan repetitive dan postur janggal dari tangan operator komputer pada saat mengetik selama 1 menit. 
Pengumpulan data yang dilakukan dalam penelitian ini yaitu menggunakan instrument penelitian berupa wawancara terstruktur hingga peneliti telah mengetahui dengan pasti tentang informasi apa yang akan diperoleh, pengukuran indeks masa tubuh, mengukur kadar GDS, melakukan pengamatan terhadap operator komputer saat mengetik,serta melakukan phalen test dan tinnel test. Penelitian ini dilakukan melalui serangkaian prosedur meliputi tahap persiapan, tahap pelaksanaan, tahap terminasi, dan analisis data.

\section{HASIL}

DAN

PEMBAHASAN

\section{Karakteristik responden}

Tabel 1 Gambaran karakteristik pegawai operator komputer yang memiliki gejala CTS di RSUD Abdul Manap Tahun 2020.

\begin{tabular}{|c|c|c|}
\hline $\begin{array}{l}\text { Kategori } \\
\text { responden }\end{array}$ & $\begin{array}{l}\text { Frekuensi } \\
\text { (n) }\end{array}$ & $\begin{array}{l}\text { Persentase } \\
(\%)\end{array}$ \\
\hline $\begin{array}{lr}\text { Responden } & \text { yang } \\
\text { memiliki gejala } \\
\text { CTS }\end{array}$ & 13 & 61,9 \\
\hline $\begin{array}{l}\text { Responden yang } \\
\text { tidak memiliki } \\
\text { gejala CTS }\end{array}$ & 8 & 38,1 \\
\hline Phalen Test (+) & 12 & 92,3 \\
\hline Phalen Test (-) & 1 & 7,7 \\
\hline Tinnel Test (+) & 9 & 69,2 \\
\hline Tinnel Test (-) & 4 & 30,8 \\
\hline
\end{tabular}

Hasil uji phalen test menunjukkan sebagian besar data phalen test yang dilakukan pada responden adalah positif. Sedangkan untuk hasil uji tinel test menunjukkan sebagian besar data tinel test pada responden adalah positif.

\section{Gambaran Usia pada Pegawai Operator Komputer yang Memiliki Gejala CTS di RSUD Abdul Manap Tahun 2020}

Tabel 2 Gambaran usia pada pegawai operator komputer yang memiliki gejala CTS di RSUD Abdul Manap tahun 2020.

\begin{tabular}{lll}
\hline Usia & Jumlah & $\begin{array}{l}\text { Persentase } \\
(\%)\end{array}$ \\
\hline 30 tahun & 4 & 30,8 \\
\hline 31-60 tahun & 9 & 69,2 \\
\hline
\end{tabular}

Berdasarkan tabel 2 menunjukkan data usia subjek yang termuda berusia 25 tahun dan tertua 46 tahun. Kategori usia secara lebih lanjut dapat dilihat pada tabel diatas.

Gambaran Jenis Kelamin pada Pegawai Operator Komputer yang Memiliki Gejala CTS di RSUD Abdul Manap Tahun 2020 Tabel 3 Gambaran Distribusi Jenis Kelamin Pegawai Operator Komputer

\begin{tabular}{lll}
\hline $\begin{array}{l}\text { Jenis } \\
\text { kelamin }\end{array}$ & Jumlah & $\begin{array}{l}\text { Persentase } \\
(\%)\end{array}$ \\
\hline Laki-laki & 4 & 30,8 \\
\hline Perempuan & 9 & 69,2 \\
\hline
\end{tabular}

Hasil data yang diperoleh menunjukkan data jenis kelamin subjek paling banyak pada perempuan. Kategori 
jenis kelamin secara lebih lanjut dapat dilihat pada tabel 3 .

Gambaran Indeks Massa Tubuh pada Pegawai Operator Komputer yang Memiliki Gejala CTS di RSUD Abdul Manap Tahun 2020

Tabel 4 Gambaran distribusi IMT pegawai operator komputer

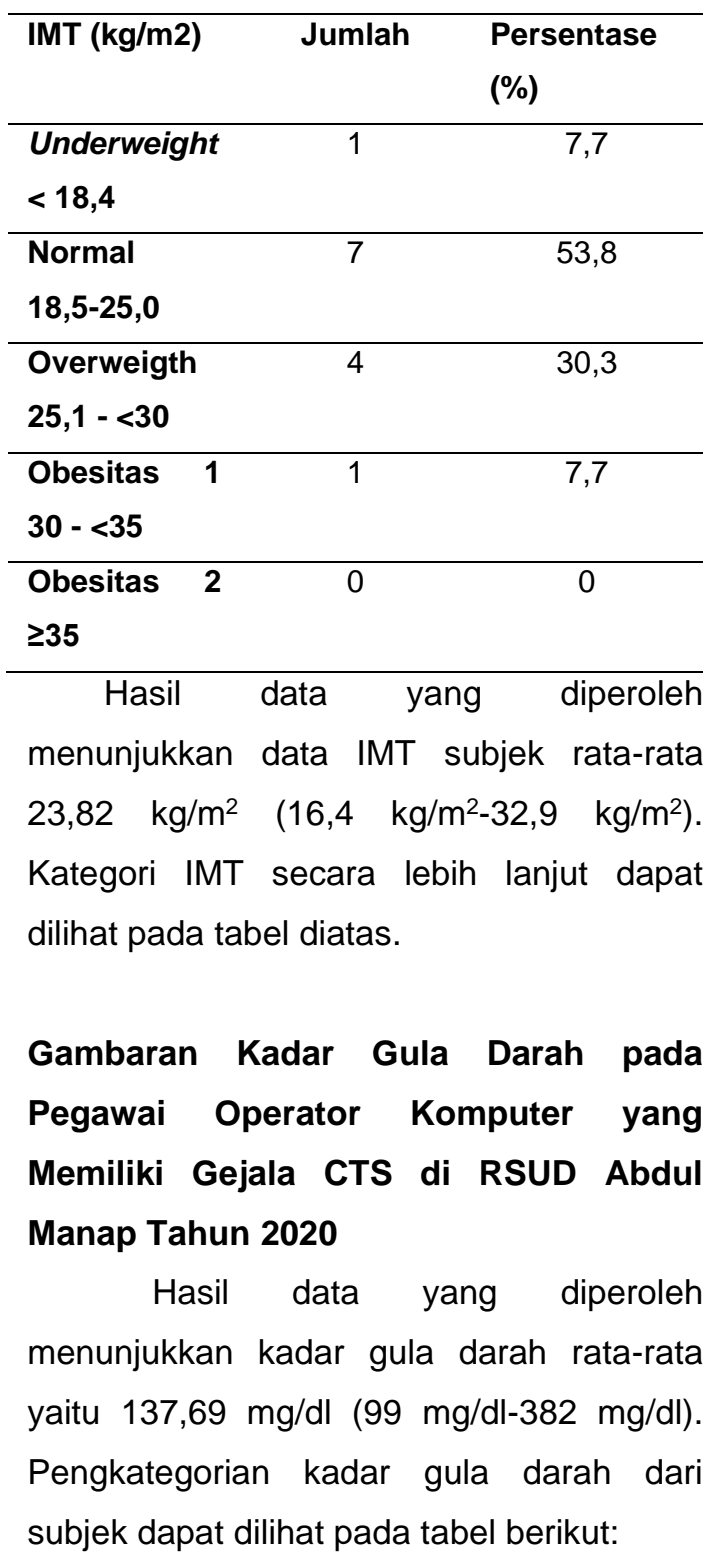

Tabel 5 Gambaran distribusi penderita DM pegawai operator komputer

\begin{tabular}{lll}
\hline DM & Jumlah & $\begin{array}{l}\text { Persentase } \\
(\%)\end{array}$ \\
\hline Positif & 1 & 7,7 \\
\hline Negatif & 12 & 92,3 \\
\hline
\end{tabular}

Gambaran Durasi Kerja Menggunakan mouse pada Pegawai Operator Komputer yang Memiliki Gejala CTS di RSUD Abdul Manap Tahun 2020

Tabel 6 Gambaran distribusi durasi kerja menggunakan mouse pegawai operator komputer

\begin{tabular}{ll}
\hline $\begin{array}{l}\text { Durasi kerja Jumlah } \\
\text { menggunakan } \\
\text { mouse }\end{array}$ & $\begin{array}{l}\text { Persentase } \\
(\%)\end{array}$ \\
\hline $\begin{array}{l}\text { 3 jam 20 } 6 \\
\text { menit perhari }\end{array}$ & 46,2 \\
\hline $\begin{array}{l}\text { 3 jam 20 } 7 \\
\text { menit perhari }\end{array}$ & 53,8 \\
\hline
\end{tabular}

Hasil data yang diperoleh
menunjukkan data durasi kerja
menggunakan mouse subjek rata-rata $\geq 3$
jam 20 menit perhari. Kategori data durasi
kerja menggunakan mouse secara lebih
lanjut dapat dilihat pada tabel diatas.
lanjut dapat dilihat pada tabel diatas. 
Gambaran Durasi Kerja Menggunakan Keyboard pada Pegawai Operator Komputer yang Memiliki Gejala CTS di RSUD Abdul Manap Tahun 2020

Tabel 7 Gambaran distribusi durasi kerja menggunakan keyboard pegawai operator Komputer

\begin{tabular}{|c|c|c|}
\hline $\begin{array}{l}\text { Durasi kerja } \\
\text { menggunakan } \\
\text { keyboard }\end{array}$ & Jumlah & $\begin{array}{l}\text { Persentase } \\
(\%)\end{array}$ \\
\hline$<4$ jam perhari & 5 & 38,5 \\
\hline$\geq 4$ jam perhari & 8 & 61,5 \\
\hline \multicolumn{3}{|c|}{$\begin{array}{l}\text { data durasi kerja menggunakan keyboard } \\
\text { subjek rata-rata } \geq 4 \text { jam perhari. Kategori } \\
\text { durasi kerja menggunakan keyboard secara }\end{array}$} \\
\hline & & \\
\hline
\end{tabular}

\section{Gambaran Masa Kerja pada Pegawai} Operator Komputer yang Memiliki Gejala CTS di RSUD Abdul Manap Tahun 2020

Tabel 8 Gambaran distribusi masa kerja sebagai pegawai operator komputer

\begin{tabular}{|c|c|c|}
\hline Masa kerja & Jumlah & $\begin{array}{l}\text { Persentase } \\
(\%)\end{array}$ \\
\hline$<4$ tahun & 2 & 15,4 \\
\hline$\geq 4$ tahun & 11 & 86,6 \\
\hline
\end{tabular}

menunjukkan data masa kerja subjek ratarata $\geq 4$ tahun. Kategori data masa kerja secara lebih lanjut dapat dilihat pada tabel diatas.

\section{Gambaran Gerakan Repetitive pada Pegawai Operator Komputer yang Memiliki Gejala CTS di RSUD Abdul Manap Tahun 2020}

Tabel 9 Gambaran gerakan repetitive pegawai operator komputer

\begin{tabular}{lll}
\hline $\begin{array}{l}\text { Gerakan } \\
\text { repetitive }\end{array}$ & Jumlah & $\begin{array}{l}\text { Persentase } \\
(\%)\end{array}$ \\
\hline $\begin{array}{l}\text { Ya: }>\quad 30 \text { kali } \\
\text { permenit }\end{array}$ & 13 & 100 \\
\hline
\end{tabular}

Tidak: $\leq \mathbf{3 0}$ kali $0 \quad 0$

permenit

Hasil penelitian terhadap pegawai operator komputer yang memiliki gejala CTS didapatkan bahwa seluruhnya mengalami gerakan repetitive dengan persentase $100 \%$. Data distribusi gerakan repetitive pegawai operator komputer disajikan dalam tabel diatas.

Gambaran Postur Janggal pada Pegawai Operator Komputer yang Memiliki Gejala CTS di RSUD Abdul Manap Tahun 2020 Tabel 10 Gambaran Distribusi Postur Janggal Pegawai Operator Komputer

\begin{tabular}{lll}
\hline Postur janggal & Jumlah & $\begin{array}{l}\text { Persentase } \\
(\%)\end{array}$ \\
\hline $\begin{array}{l}\text { Ya: } \geq 30 \text { kali } \\
\text { permenit }\end{array}$ & 13 & 100
\end{tabular}

Tidak: $<30$ kali $0 \quad 0$ permenit

Hasil penelitian terhadap pegawai operator komputer yang memiliki gejala CTS didapatkan bahwa seluruhnya mengalami postur janggal dengan persentase $100 \%$. Data distribusi postur janggal pegawai operator komputer disajikan dalam tabel diatas. 
Gambaran Usia pada Pegawai Operator Komputer yang Memiliki Gejala CTS di RSUD Abdul Manap Tahun 2020

Berdasarkan hasil penelitian ini didapatkan responden sebanyak 13 orang dan diketahui rincian proporsi usia sebagai berikut: Responden yang memiliki gejala CTS berusia $\leq 30$ tahun lebih sedikit jumlahnya, yaitu $30,8 \%$ (4 orang) dibandingkan dengan responden yang berusia 31-60 tahun yang lebih banyak jumlahnya, yaitu $69,2 \%$ (9 orang).

Hasil penelitian ini sejalan dengan penelitian yang dilakukan oleh Veni Selviyati, Anita Camelia, Elvi Sunarsih tentang determinan kejadian CTS pada petani penyadap pohon karet di desa Karang Manik Kecamatan Belitang II Kabupaten Oku Timur yang menunjukkan bahwa mayoritas petani penyadap pohon karet yang memiliki karakteristik usia $\geq 30$ tahun yaitu sebanyak 80 orang $(79,2 \%){ }^{12}$ Penelitian lain yang di lakukan oleh Dede Solikhin Al-kirom di Yogyakarta yang menunjukkan bahwa mayoritas penderitas CTS memiliki karakteristik Usia >29 tahun atau sebanyak $80,4 \cdot{ }^{13}$

\section{Gambaran Jenis Kelamin pada Pegawai} Operator Komputer yang Memiliki Gejala CTS di RSUD Abdul Manap Tahun 2020

Dari 13 responden didapatkan bahwa pegawai operator komputer yang memiliki gejala CTS dengan jenis kelamin laki-laki memiliki persentase sebesar 30,8\% (4 orang), sedangkan yang berjenis kelamin perempuan persentasenya sebesar $69,2 \%$ (9 orang), sehingga perbandingan antara laki-laki dan perempuan sebesar 0,44: 1 .
Hasil penelitian ini sejalan dengan penelitian yang dilakukan oleh Siti Rohmah tentang analisis hubungan faktor-faktor individu dengan CTS pada pekerja konveksi menunjukkan bahwa sebesar $60 \%$ pekerja dengan jenis kelamin perempuan mengalami CTS, sedangkan sebanyak hanya $30 \%$ pekerja dengan jenis kelamin laki-laki mengalami CTS. ${ }^{14}$

\section{Gambaran Indeks Massa Tubuh pada Pegawai Operator Komputer yang Memiliki Gejala CTS di RSUD Abdul Manap Tahun 2020}

Didapatkan bahwa mayoritas $(53,8 \%)$ dari responden memiliki IMT yang normal, diikuti dengan IMT overweight $(30,8 \%)$.

Hasil penelitian ini sejalan dengan penelitian oleh Siti Rohmah tentang analisis hubungan faktor-faktor individu dengan CTS pada pekerja konveksi menunjukkan bahwa sebesar $52,5 \%$ pekerja memiliki IMT normal, sebesar $17,5 \%$ pekerja yang memiliki IMT kurus (underweight), dan sebesar $30 \%$ pekerja yang memiliki IMT gemuk (overweight). ${ }^{14}$

Penjelasan dari literatur sebelumnya yang telah peneliti sampaikan mengatakan bahwa IMT yang overweight dan obesitas merupakan salah satu faktor resiko dari kejadian CTS. ${ }^{15}$ Dalam penelitian ini hanya memiliki 1 orang responden yang memiliki IMT overweight sehingga tidak dapat memenuhi teori berdasarkan literatur tersebut.

Hasil studi saya menunjukkan bahwa responden penelitian saya memiliki lebih banyak IMT yang normal karena 
jumlah responden yang sedikit. Faktor risiko yang lebih signifikan memunculkan gejala pada penelitian saya kemungkinan adalah faktor lain yaitu postur janggal dan gerakan repetitive.

\section{Gambaran Diabetes Mellitus pada \\ Pegawai Operator Komputer yang Memiliki Gejala CTS di RSUD Abdul Manap Tahun 2020}

Untuk menentukan kriteria penilaian DM diketahui dengan cara mengukur kadar gula darah sewaktu, kriteria DM diperoleh apabila gula darah sewaktu $\geq 200 \mathrm{mg} / \mathrm{dl}$ dan tidak DM apabila gula darah < 200mg/dl. Berdasarkan penelitian didapatkan pegawai operator komputer yang menderita DM sebanyak $7,7 \%$ (1 orang) dan yang tidak menderita DM sebanyak 92,3\% (12 orang).

Hasil penelitian ini sejalan dengan penelitian oleh Marisa Nada Debora, dkk tentang gambaran faktor-faktor yang terkait dengan kejadian CTS pada ibu rumah tangga di Desa Guji baru menunjukkan bahwa sebesar 3 orang (30\%) pekerja menderita DM dan sebesar 7 orang $(70 \%)$ tidak menderita DM pada kelompok yang positif mengalami CTS. ${ }^{16}$

Penjelasan dari literatur sebelumnya yang telah peneliti sampaikan mengatakan bahwa DM merupakan faktor resiko pada CTS, namun dalam penelitian ini hanya memiliki 1 orang responden yang menderita DM, sehingga tidak dapat memenuhi teori berdasarkan literatur tersebut.

\section{Gambaran Durasi Kerja Menggunakan Keyboard dan Mouse pada Pegawai Operator Komputer yang Memiliki Gejala CTS di RSUD Abdul Manap Tahun 2020}

Penggolongan durasi kerja menggunakan keyboard pada pegawai operator komputer terbagi menjadi 2, yaitu $<4$ jam perhari dan $\geq 4$ jam perhari. Dari hasil penelitian didapatkan pegawai operator komputer yang bekerja dengan menggunakan keyboard $<4$ jam perhari sebanyak 38,5\% (5 orang )dan yang bekerja menggukan keyboard $\geq 4$ jam perhari sebanyak $61,5 \%$ (8 orang).

Adapun penggolongan durasi kerja menggunakan mouse pada pegawai operator komputer terbagi menjadi 2, yaitu $<3$ jam 20 menit perhari dan $\geq 3$ jam 20 menit perhari. Dari hasil penelitian didapatkan pegawai operator komputer yang bekerja dengan menggunakan mouse < 3 jam 20 menit perhari sebanyak 46,2\% (6 orang) dan yang bekerja menggukan mouse $\geq 3$ jam 20 menit perha sebanyak $53,8 \%$ (7 orang).

Hasil penelitian dari kedua variabel diatas sejalan dengan penelitian yang dilakukan oleh Triana Nur Aripin, dkk tentang hubungan durasi mengetik komputer dan posisi mengetik komputer dengan gejala CTS pada karyawan Universitas Islam Bandung yang menunjukkan bahwa sebanyak 19 orang $(59,3 \%)$ yang memiliki gejala CTS mempunyai durasi kerja yang lama, sedangkan 13 orang $(40,7 \%)$ yang memiliki gejala CTS mempunyai durasi kerja yang sebentar. ${ }^{17}$ 


\section{Gambaran Masa Kerja pada Pegawai Operator Komputer yang Memiliki Gejala CTS di RSUD Abdul Manap Tahun 2020}

Berdasarkan

penelitian

penggolongan masa kerja pada pegawai operator komputer digolongkan menjadi 2 , yaitu $<4$ tahun dan $\geq 4$ tahun. Responden yang telah bekerja selama $<4$ tahun sebanyak $15,4 \%$ (2 orang) dan yang telah bekerja selama $\geq 4$ tahun $84,6 \%$ (11 orang).

Hasil penelitian ini sejalan dengan penelitian yang dilakukan oleh Muthoharoh, Sarinah Basri K dan Tating Nuraeni tentang faktor yang berhubungan dengan kejadian CTS pada karyawan SPBE di Indramayu menunjukkan bahwa sebanyak 31 orang $(77,5 \%)$ yang memiliki masa kerja selama 4-7 tahun termasuk dalam kategori yang berisiko CTS, sedangkan sebanyak 9 orang $(22,5 \%)$ yang memiliki masa kerja 1-3 tahun tidak termasuk dalam kategori yang berisiko CTS. ${ }^{18}$

Penelitian lain yang dilakukan oleh Kintan Nafasa, dkk tentang hubungan masa kerja dengan keluhan CTS pada karyawan pengguna komputer di Bank BJB cabang Subang juga menunjukkan bahwa sebanyak $63 \%$ (34 orang) pekerja dengan masa kerja $\geq 4$ tahun yang memiliki risiko CTS, sedangkan sebanyak 37\% (20 orang) pekerja memiliki masa kerja $<4$ tahun yang tidak memiliki risiko CTS. ${ }^{9}$

\section{Gambaran Gerakan Repetitive pada Pegawai Operator Komputer yang Memiliki Gejala CTS di RSUD Abdul Manap Tahun 2020}

Berdasarkan hasil penelitian pada pegawai operator komputer yang memiliki gejala CTS, didapatkan bahwa semua pegawai operator komputer mengalami gerakan repetitive dengan persentase $100 \%$.

Hasil penelitian ini sejalan dengan penelitian yang dilakukan oleh Jawahirun Nadhifah, dkk tentang keluhan CTS pada pekerja sortasi daun tembakau di Jember yang menyatakan bahwa sebanyak 38 orang $(63,3 \%)$ responden mengalami CTS dengan gerakan repetitive $>30$ kali permenit, sedangkan sebanyak 22 orang $(36,7 \%)$ mengalami keluhan CTS dengan gerakan repetitive $\leq 30$ kali permenit. Hal ini menunjukkan bahwa pekerja dengan gerakan repetitive $>30$ kali permenit memiliki persentase risiko terkena CTS lebih tinggi dibandingkan dengan pekerja dengan gerakan repetitive $\leq 30$ kali permenit. ${ }^{19}$

Penelitian lain yang dilakukan oleh Ratna Kurnia Sari, dkk tentang workload, repetitive wrist movements, years of service with carpal tunnel syndrome juga menunjukkan bahwa sebanyak 34 orang $(68 \%)$ dari total responden memiliki gerakan repetitive $>30$ kali permenit, sedangkan sebanyak 16 orang (32\%) memiliki gerakan repetitive $\leq 30$ kali permenit. ${ }^{20}$ 


\section{Gambaran Postur Janggal pada Pegawai Operator Komputer yang Memiliki Gejala CTS di RSUD Abdul Manap Tahun 2020}

Berdasarkan hasil penelitian pada pegawai operator komputer yang memiliki gejala CTS, didapatkan bahwa semua pegawai operator komputer mengalami postur janggal dengan persentase $100 \%$.

Hasil penelitian ini sejalan dengan penelitian yang dilakukan oleh Muthoharoh, Sarinah Basri K, Tating Nuraeni tentang faktor yang berhubungan dengan kejadian CTS pada karyawan SPBE di Indramayu menunjukkan bahwa dari 40 karyawan SPBE yang mengalami postur janggal sebanyak 28 orang $(70 \%)$ dan yang memiliki postur yang baik sebanyak 12 orang $(30 \%) .{ }^{18}$

\section{KESIMPULAN}

Berdasarkan faktor risiko individu dari 13 responden yang memiliki gejala CTS diketahui sebagian besar berusia 31 60 tahun sebanyak 9 orang $(69,2 \%)$, berjenis kelamin perempuan sebanyak 9 orang $(69,2 \%)$, dengan IMT normal sebanyak 7 orang $(53,8 \%)$ dan kriteria DM negative sebanyak 12 orang (92,7\%).

Berdasarkan faktor risiko pekerjaan dari ke 13 responden yang memiliki gejala CTS diperoleh responden memiliki durasi kerja menggunakan keyboard sebagian besar $<4$ jam perhari sebanyak 8 orang $(61,5 \%)$, responden memiliki durasi kerja menggunakan mouse sebagian besar $>3$ jam 20 menit perhari sebanyak 7 orang $(53,8 \%)$, dengan masa kerja responden sebagai operator komputer sebagian besar $\geq 4$ tahun berjumlah 11 orang $(86,6 \%)$, dan untuk gerakan repetitive dan postur janggal seluruhnya berisiko CTS dengan persentase $100 \%$.

\section{DAFTAR PUSTAKA}

1. Basuki R, Jenie M N, Fikri Z. Faktor Prediktor Carpal Tunnel Syndrome (CTS) pada Pengrajin Alat Tenun Bukan Mesin (ATBM). Jurnal Kedokteran Muhammadiyah. 2015;4: 1-7

2. Bahrudin M, Perdana R L P, Sultana H F A. Hubungan Masa Kerja dengan Kejadian CTS pada Pekerja Pemetik Daun Teh. Jurnal Universita Muhammadiyah Malang. 2015;11(2): 114-118

3. Sitompul Y R M B. Resiko Jenis Pekerjaan dengan Kejadian Carpal Tunnel Syndrome (CTS). Jurnal IImiah WIDYA. 2019;5(3): 1-7

4. Setyawan H. Risk Factors of Carpal Tunnel Syndrome in Food-Packing Workers Karanganyar. Kesmas: National Public Health Journal. 2017;11(3): 123-126.

5. Wardana E R, Jayanti S, Ekawati. Faktor-faktor yang Berhubungan dengan Kejadian Carpal Tunnel Syndrome (CTS) pada Pekerja Unit Assembling PT X Kota Semarang. Jurnal Kesehatan Masyarakat. 2018;6(5): 502-509

6. Al kirom D S, Ardi S Z. Hubungan Antara Usia, Durasi Kerja dan Gerakan Repatitif Menekan Nozzle dengan Keluhan Subyektif Carpal Tunnel Syndrom (CTS) pada Petugas Operator Pengisi BBM di Tiga SPBU Kota Yogyakarta Tahun 2019. (Disertasi doktoral, Universitas Ahmad Dahlan). 2020; 1-15

7. Juniar G A R, TriWahyudi A. Hubungan Antara Masa Kerja Terhadap Keluhan Carpal Tunnel Syndrome (CTS) pada Pegawai Perempuan di Kampus Universitas Dhayana Pura yang Bekerja Menggunakan Komputer. 2015;1(2): 162-168 
8. Chen L H, Li C Y, Kuo L C, Wang L Y, Kuo K N, Jou I M, et al. Risk of hand syndromes in patients with diabetes mellitus: a population-based cohort study in Taiwan. Medicine (Baltimore). 2015;94(41): 1-5

9. Nafasa K, Yuniarti, Nurimaba N, Tresnasari C, Wagiono C. Hubungan Masa Kerja dengan Keluhan Carpal Tunnel Syndrome pada Karyawan Pengguna Komputer di Bank BJB Cabang Subang. Jurnal Integrasi Kesehatan dan Sains. 2019;1(1): 40-44

10. Chairunnisa P, Widjasena B, Suroto. Hubungan Gerakan Repetitif dan Lama Kerja dengan Keluhan Carpal Tunnel Syndrome pada Mahasiswa Teknik Arsitektur. Jurnal Kesehatan Masyarakat. 2015;3(3): 563-571

11. Zulkarnain. Hubungan Indeks Masa Tubuh (IMT) dengan Kejadian Carpal Tunnel Syndrome (CTS) pada Penderita CTS di RS Universitas Hasanudi dan RSUP Wahidin Sudirohusodo Makassar Periode 2014-2017. Skripsi. Universitas Hasanuddin, Makassar; 2017

12. Selviyati V, Camelia A, Sunarsih E. Analisis Determinan Kejadian Carpal Tunnel Syndrome (Cts) Pada Petani Penyadap Pohon Karet Di Desa Karang Manik Kecamatan Belitang li Kabupaten Oku Timur. Jurnal Ilmu Kesehatan Masyarakat. 2016;7(3): 198-208

13. Kirom A, Solikhin D. Hubungan Antara Usia, Durasi Kerja dan Gerakan Repetitif Menekan Nozzle dengan Keluhan Subyektif Carpal Tunnel Syndroem (CTS) pada Petugas Operator Pengisi BBM di Tiga SPBU Kota Yogyakarta Tahun 2019 (Doctoral dissertation, Universitas Ahmad Dahlan). 2020

14. Rohmah, S. Analisis Hubungan Faktor-Faktor Individu dengan Carpal Tunnel Syndrome (CTS) pada Pekerja Konveksi. Seminar Nasional IENACO, 2016: 73-79

15. Pourmemari M. Risk Factor for Carpal Tunnel Syndrome (Academic Dissertation). Tampere University; Faculty of Social Sciences Finland; 2019

16. Debora M N, Suparto S, Tanpomas I. Gambaran Faktor-Faktor yang Terkait dengan Kejadian Carpal Tunnel Syndrome pada Ibu Rumah Tangga di Desa Guji Baru. Jurnal Kedokteran Meditek. 2018;24(67): 26-31

17. Aripin T N, Rasjad A S, Nurimaba N, Djojosugito M A, Irasanti S N. Hubungan Durasi Mengetik Komputer dan Posisi Mengetik Komputer dengan Gejala Carpal Tunnel Syndrome (CTS) pada Karyawan Universitas Islam Bandung. Jurnal Integrasi Kesehatan dan Sains. 2019;1(2): 97-101

18. Nuraeni T. Faktor yang Berhubungan dengan Kejadian Carpal Tunnel Syndrome (CTS) pada Karyawan SPBE Di Indramayu. Afiasi: Jurnal Kesehatan Masyarakat. 2018;3(2). 37-44

19. Nadhifah J, Hartanti R I, Indrayani R. Keluhan Carpal Tunnel Syndrome pada Pekerja Sortasi Daun Tembakau (Studi

20. Sari R K, Prasetio D B, Wardani R S. Workload, Repetitive Wrist Movements, Years of Service With Carpal Tunnel Syndrome. Jurnal Riset Kesehatan. 2020;9(2): 159-164. 